\title{
PERMAINAN KARTU GAMBAR UNTUK MENINGKATKAN KEBERHASILAN MEMBACA PADA SISWA SDN 32 SUNGAI JARING Nurhasnah
}

SD Negeri 32 Sungai Jaring

E-mail: nurhasnaadek@yahoo.co.id

\begin{tabular}{l}
\hline Diterima: \\
7 Juli 2021 \\
Direvisi: \\
10 Juli 2021 \\
Disetujui: \\
14 Juli 2021
\end{tabular}

Pendidikan adalah usaha dasar dan terencana untuk mewujudkan suasana belajar dan proses pembelajaran agar peserta didik secara aktif mengembangkan potensi dirinya untuk memiliki kekuatan spiritual keagamaan, pengendalian diri, kepribadian, kecerdasan, akhlak mulia, serta ketrampilan yang diperlukan dirinya, masyarakat, bangsa, dan negara. Penelitian ini bertujuan untuk mendeskripsikan bagaimana penggunaan permainan kartu bergambar (flashcard) pada siswa kelas 1 SD Negeri 32 Sungai Jaring Tahun Ajaran 2018/2019 dan untuk meningkatkan kemampuan membaca Permulaan Bahasa Indonesia siswa kelas I SD. Penelitian ini merupakan Penelitian Tindakan Kelas (PTK) dilaksanakan dalam 2 siklus dengan 3 kali pertemuan tiap siklusnya dengan jumlah siswa sebanyak 10 siswa. Berdasarkan hasil penelitian ini, penggunaan media gambar dalam pembelajaran dapat mengatasi kesulitan belajar membaca permulaan pada siswa kelas I SD Negeri 32 Sungai Jaring dibandingkan dengan pembelajaran yang sebelum menggunakan media gambar. Pada pra tindakan persentase ketuntasan siswa baru mencapai $30 \%$, setelah dilaksanakan tindakan pada siklus I persentase ketuntasan siswa meningkat menjadi $60 \%$, pada siklus II meningkat menjadi $90 \%$.

Kata Kunci: Permainan kartu bergambar, kemampuan membaca, Bahasa Indonesia

\begin{abstract}
Education is a basic and planned effort to create a learning atmosphere and learning process so that students actively develop their potential to have religious spiritual strength, self-control, personality, intelligence, noble character, and skills needed by themselves, society, nation and state. This study aims to describe how the use of picture card games (flashcards) in 1st grade students of SD Negeri 32 Sungai Jaring in the 2018/2019 academic year and to improve the ability to read Beginning Indonesian for first grade elementary school students. This research is a Classroom Action Research (CAR) carried out in 2 cycles with 3 meetings in each cycle with a total of 10 students. Based on the results of this study, the use of image media in learning can overcome difficulties in learning to read beginning in first grade students of SD Negeri 32 Sungai Jaring compared to learning before using image media. In the pre-action the percentage of student completeness only reached $30 \%$, after the action was carried out in the first cycle the percentage of student completeness increased to 60\%, in the second cycle it increased to $90 \%$
\end{abstract}

Keywords: Picture card game, reading ability, Indonesian 


\section{Pendahuluan}

Pendidikan adalah usaha yang mendasar dan terencana untuk mewujudkan suasana belajar dan proses pembelajaran bagi peserta didik untuk secara aktif mengembangkan potensi spiritual keagamaannya, kekuatan, pengendalian diri, kepribadian, kecerdasan, akhlak mulia, serta keterampilan yang diperlukan dirinya, masyarakat, bangsa, dan Negara (Asy'ari, 2017). Lahirnya UU no. 20 Tahun 2004 tentang Sistem Pendidikan Nasional berdampak positif bagi pembelajaran bahasa Indonesia. Hal ini mencerminkan adopsi membaca, menulis dan berhitung sebagai keterampilan bahasa dasar yang menjadi perhatian dan kegiatan awal dan berkelanjutan di sekolah dasar atau Madrasah Ibtidaiyah dari Kelas I. Bahasa memainkan peran kunci dalam perkembangan intelektual, sosial dan emosional siswa dan mendukung sukses dalam mempelajari semua bidang studi. Pendidikan bahasa diharapkan menolong peserta didik memahami dirinya, budayanya, serta budaya orang lain, mengemukakan gagasan serta perasaan, berpartisipasi dalam warga yang memakai bahasa tersebut, serta menciptakan dan memakai keahlian analitis serta imaginatif yang terdapat dalam dirinya (Hidayah, 2015).

Hakikatnya belajar bahasa merupakan belajar komunikasi. Dengan pendekatan komunikatif ini siswa wajib diberi peluang untuk melaksanakan komunikasi baik secara lisan ataupun tulisan. Siswa sanggup berbicara dengan memakai bahasa Indonesia yang baik serta benar, hingga siswa butuh dilatih sebanyak-banyaknya ataupun diberi peluang seluas-luasnya buat melaksanakan aktivitas berbicara. Dengan memikirkan ciri anak yang lebih mencermati terhadap suatu yang menarik atensi mereka, membangkitkan atensi serta motivasi belajar dan melatih imajinasi anak, hingga pelaksanaan media foto dalam pendidikan bahasa Indonesia dapat meningkatkan keahlian bercerita anak. Proses belajar tidak dapat dilepaskan dari kehidupan tiap manusia. Sebab belajar merupakan sesuatu proses yang terjalin pada diri tiap orang terhadap lingkungannya. Proses belajar itu terjalin karena adanya interaksi antara seorang dengan lingkungannya. Oleh sebab itu, belajar bisa terjalin kapan saja serta dimana saja. Salah satu tanda- tanda kalau seorang itu sudah belajar merupakan terdapatnya pergantian tingkah laku pada diri orang itu yang bisa jadi diakibatkan oleh terbentuknya pergantian pada tingkatan pengetahuan, keahlian, ataupun perilakunya. Aktivitas yang menarik serta mengasyikkan dapat menjadi dorongan berarti dalam suatu proses belajar (Halim, 2012).

Salah satu fokus pembelajaran Bahasa di Sekolah Dasar yang memegang peranan penting ialah pembelajaran membaca, tanpa memiliki kemampuan membaca yang memadai sejak dini, anak akan mengalami kesulitan belajar dikemudian hari. Kemampuan membaca menjadi dasar utama tidak saja pembelajaran bahasa sendiri, tetapi juga bagi pembelajaran mata pelajaran lain. Dengan membaca siswa akan memperoleh pengetahuan yang sangat bermanfaat bagi pertumbuhan dan perkembangan daya nalar, sosial dan emosional (Gunawan, 2020). Kegiatan yang menarik dan menyenangkan merupakan suatu bagian penting dalam mendorong perkembangan bahasa, karena anak harus mampu mengungkapkan dan menggunakan kata-kata, untuk mendorong anak agar mampu mengungkapkan diri dengan kata-kata, maka kegiatan yang akan dilakukan adalah melalui permainan bahasa dalam bentuk permainan berbicara atau permainan deskriptif. Permainan deskriptif adalah permainan yang menuntut anak-anak untuk menguraikan benda dengan mendorong anak untuk mencari kata-kata dan membantu mereka berbicara serta berpikir dengan lebih jelas, salah satu contohnya permainan pemberian gambar (Kurnia, 2019). Salah satu fokus pembelajaran Bahasa di Sekolah Dasar yang memegang peranan penting ialah pembelajaran membaca, tanpa memiliki kemampuan membaca yang memadai sejak dini, anak akan mengalami kesulitan belajar dikemudian hari.(Octavia, 2020).

Peranan guru kelas I memegang peranan penting dalam bidang pengajaran Bahasa Indonesia khususnya membaca. Tanpa mempunyai keahlian membaca yang mencukupi 
semenjak dini hingga anak hendak hadapi kesusahan belajar di setelah itu hari (Madyawati, 2016). Keahlian membaca menjadi dasar utama untuk pelajaran Bahasa Indonesia sendiri, dan untuk belajar mata pelajaran lain.

Guru hanya bertugas menuntaskan sasaran modul dalam kurikulum tiap akhir semester ataupun tiap tahun (Idzhar, 2016). Tetapi, tidak mencermati masih ada ketidakseimbangan antara sasaran kurikulum dengan energi serap yang dicapai partisipan didik. Guru kurang memahami siswa secara merata sehingga tidak dapat membedakan antara siswa yang lemah dengan siswa yang pandai dalam menerima pelajaran. Pembagian tugas mengajar kelas harus sesuai keahlian guru, khususnya guru kelas I harus guru yang dapat memahami siswa secara totalitas (Ihsan, 2021). Pendidikan Bahasa Indonesia yang diterapkan di sekolah belum menggunakan media pendidikan selaku penunjang aktivitas pendidikan. Dengan demikian butuh pemanfaatan media pendidikan supaya siswa mudah menangkap serta menggapai tujuan pendidikan. Salah satu media pendidikan yang bisa digunakan merupakan media foto. Media foto ini menarik untuk siswa sebab dari media tersebut banyak tema yang bisa diseleksi buat dibesarkan serta seluruh siswa mendapatkan peluang yang sama tidak hanya itu mereka memperoleh pengalaman yang berharga serta secara tidak langsung bisa tingkatkan atensi mereka terhadap pendidikan membaca.

Penggunaan metode permainan akan lebih efektif apabila didukung dengan adanya media sebagai alat bantu pembelajaran. Penggunaan alat bantu sebagai media pembelajaran diharapkan mampu membantu proses belajar. Pemakaian media dalam proses pembelajaran dapat membangkitkan keinginan dan minat, membangkitkan motivasi, memberikan rangsangan kegiatan belajar, bahkan membawa pengaruh psikologis siswa. Media dapat menarik minat belajar dan konsentrasi anak untuk memahami pelajaran (Dewi, 2019). Berdasarkan uraian diatas, tujuan dilaksanan penelitian ini adalah untuk mendeskripsikan bagaimana penggunaan permainan kartu bergambar (flashcard) pada siswa kelas 1 SD Negeri 32 Sungai Jaring Tahun Ajaran 2018/2019 dan untuk meningkatkan kemampuan membaca Permulaan Bahasa Indonesia siswa kelas I SD.

\section{Metode Penelitian}

Penelitian ini menggunakan penelitian tindakan kelas (classroom action research) yang berkolaborasi dengan teman sejawat. Suharsimi Arikunto yang mneyebutkan tujuan utama penelitian tindakan kelas ini adalah untuk memecahkan masalah yang nyata yang ada di kelas, yang tidak saja bertujuan memecahkan masalah, tetapi sekaligus mencari jawaban mengapa hal itu dapat dipecahkan melalui tindakan yang dilakukan (Rahman, 2018).

PTK adalah sebuah bentuk kegiatan refleksi diri yang dilakukan oleh para pelaku pendidikan dalam suatu situasi kependidikan untuk memperbaiki rasionalitas dan keadilan tentang: (a) Pratik kependidikan, (b) pemahaman tentang praktik kependidikan, (c) Situasi tempat praktik dilaksanakan (Ananda, 2019). Suharsimi Arikunto menyebutkan bahwa Penelitian tindakan kelas (Classroom Action Rresearch) yaitu penelitian yang dilakukan oleh guru di dalam kelas bekerjasama dengan peneliti yang menekankan pada penyempurnaan atau peningkatan proses pembelajaran (Hanifah, 2014). Alasan penulis menggunakan PTK adalah untuk memperbaiki proses pembelajaran menjadi lebih baik. Adapun kelebihan PTK yang dikemukakan oleh Shumsky yaitu: (1) Kerjasama dalam PTK menimbulkan rasa saling memiliki, (2) Kerjasama dalam PTK mendorong kreativitas dan pemikiran kritis dalam hal ini guru sekaligus sebagai peneliti, (3) Kerjasama dalam PTK menghasilkan perubahan yang positif, (4) Kerjasama dalam PTK meningkatkan kesepakatan dalam menyelesaikan masalah yang dihadapi (Ginting, 2019). 
Penelitian ini dikembangkan secara bersama - sama oleh peneliti dan kolaborator untuk menentukan kebijakan dan pembangunan. Variabel penelitian ini terdiri atas dua variabel yaitu variabel bebas dan variable terikat. Variabel bebas dari penelitian ini adalah teknik media kartu kata dan variabel terikat penelitian ini adalah membaca kata (kata). Penelitian tindakan kelas merupakan proses kegiatan yang dilakukan di kelas. Pada siklus (satu) siklus, yang terdiri dari tahap perencanaan, Pelaksanaan (action) dan refleksi atau perenungan. Berlanjut tidaknya ke siklus II tergantung dari hasil refleksi siklus I.

Tabel 1. Data dikumpulkan melalui observasi dan tes lisan. Adapun kriteria penilaiannya ada tiga tingkatan sebagai berikut:

\begin{tabular}{llc}
\hline No & Kategori & Bobot \\
\hline 1 & $\begin{array}{l}\text { BS = bisa } \\
\text { Anak bisa membaca kata yang telah disediakan dengan benar dan jelas } \\
\text { secara mandiri }\end{array}$ & 2 \\
2 & $\begin{array}{l}\text { Dengan Bantuan (BSB) } \\
\text { Anak bisa membaca kata yang telah disediakan dengan benar dan jelas } \\
\text { secara mandiri bila diberikan bantuan }\end{array}$ & 1 \\
3 & $\begin{array}{l}\text { Tidak bisa (TB) } \\
\text { Anak tidak bisa membaca kata yang telah disediakan dengan benar dan } \\
\text { jelas secara mandiri }\end{array}$ & 0 \\
\hline
\end{tabular}

Subjek pada penelitian ini 10 orang anak kelas I yang mengalami lambat belajar. Penelitian ini dilaksanakan di Kelas I SD Negeri 32 Sungai Jaring yang dilaksanakan pada Tahun Pelajaran 2018/2019.

Data dikumpulkan dalam penelitian ini, meliputi data primer dan data sekunder. Data primer ialah data-data yang diperoleh langsung dari lapangan, seperti dari sumber informasi/sampel. Sedangkan data sekunder ialah data-data penelitian yang dipeoleh dari bahan bacaan, seperti buku, surat kabar, dokumen dan lain sebagainya. Pengumpulan data dilakukan dengan metode observasi, wawancara, dokumentasi dan catatan lapangan.

Observasi atau pengamatan adalah suatu teknik atau cara mengumpulkan data dengan jalan mengadakan pengamatan terhadap kegiatan yang sedang berlangsung (Lindawati, Asriyani, \& Anggayana, 2019). Observasi ini dilakukan sebelum tindakan dimulai dan pada saat pelaksanaan tindakan dan untuk mengetahui hasil pencapaian dari eksperimen penggunaan metode bercerita dengan media flashcard terhadap kemampuan membaca anak SD Kelas I. Teknik pengumpulan data yang digunakan dalam penelitian ini selain observasi adalah test. Test ini dilakukan untuk mengetahui sejauh mana kemampuan membaca permulaan siswa. Test yang dimaksud adalah test membaca permulaan.

Berdasarkan hasil pengamatan di SD Negeri 32 Sungai Jaring, tingkat kemampuan membaca anak masih kurang optimal, anak masih kurang tertarik dengan membaca. Salah satu penyebabnya karena guru jarang menggunakan media yang bias merangsang kemampuan anak untuk membaca, sehingga anak akan lebih antusias untuk belajar membaca.

1. Perencanaan Tindakan

a. Menetapkan Subjek yang akan digunakan sebagai kelas penelitian

b. Membuat RPP

c. Mempersiapkan media pembelajaran yaitu flashcard (gambar, tulisan) yang disesuaikan dengan tema pembelajaran.

d. Melaksanakan simulasi cara penggunaan metode bercerita dengan media flashcard dalam kegiatan pembelajaran.

2. Pelaksanaan Tindakan

Pelaksanaan tindakan pembelajaran membaca dini dilaksanakan melalui prosedur sebagai berikut. 
a. Pelaksanaan pembelajaran membaca dini dimulai dengan perencanaan.

b. Melaksanakan tindakan pembelajaran sesuai dengan indikator kemampuan bahasa yang didukung dengan pemilihan metode bercerita dengan media flashcard yang sesuai dengan indikator.

c. Observasi terhadap penggunaan metode bercerita dengan media flashcard dalam meningkatkan kemampuan membaca dini.

d. Refleksi terhadap tindakan yang sudah dilaksanakan berdasarkan temuan selama proses pembelajaran (hasil refleksi ini dijadikan sebagai rujukan dalam perbaikan pelaksanaan tindakan berikutnya.

e. Prosedur ini dilakukan secara berulang sampai memperoleh perubahan

f. kemampuan membaca dini sesuai dengan yang diharapkan.

3. Pengamatan (Observasi)

Pengamatan dapat dilaksanakan dengan pedoman pengamatan (format, daftar cek), catatan lapangan, jurnal harian, observasi aktifitas di kelas, penggambaran interaksi dalam kelas, alat perekam elektronik atau pemetaan kelas mills dalam. Pengamatan dilakukan selama proses penelitian tindakan dilaksanakan mulai dari siklus I dan siklus II. Melalui pengamatan ini diharapkan dapat mengetahui kekurangan-kekurangan dalam pelaksanaan tindakan, sebagai modifikasi rancangan dapat dilakukan secepatnya. Dengan kata lain pengamatan dilakukan untuk mengumpulkan bukti hasil tindakan agar dapat dievaluasi dan dijadikan landasan dalam melakukan refleksi. Pengamatan dilakukan secara terus menerus mulai dari siklus I sampai siklus yang diharapkan bisa tercapai. Pengamatan yang dilakukan dalam satu siklus memberikan pengaruh pada penyusunan tindakan yang dilakukan pad siklus berikutnya.

4. Refleksi

Refleksi merupakan kegiatan mengkaji semua informasi yang diperoleh dari penelitian untuk mengetahui hal-hal yang dirasakan sesudah berjalan baik dan bagian mana yang belum atau dikatakan sebagai evakuasi diri. Kegiatan refleksi dilaksanakan secara kolaboratif antara peneliti dan guru untuk mendiskusikan hasil dari kegiatan yang sudah dilakukan. Beberapa tindakan yang dilakukan pada saat refleksi, yaitu:

a. Mengidentifikasi kembali aktivitas yang telah dilakukan selama proses pembelajaran berlangsung pada setiap siklus.

b. Menganalisis pengolahan data hasil evaluasi dan merinci kembali tindakan pembelajaran yang telah dilaksanakan.

c. Menetapkan tindakan selanjutnya berdasarkan hasil analisis kegiatan.

d. Jika pelaksanaan tindakan telah tercapai maka penelitian dianggap selesai, tetapi jika belum tercapai kembali pada siklus rencana pembelajaran berikutnya.

Teknik analisis data yang digunakan dalam penelitian ini menggunakan analisis data kualitatif dengan model analisis interaktif yang dikembangkan oleh Miles dan Huberman yang mengemukakan bahwa analisis interaktif tersebut memiliki tiga komponen kegiatan yang saling terkait satu sama lain. Tiga komponen itu antara lain: reduksi data, beberan (display) data dan penarikan kesimpulan. Reduksi data merupakan proses menyeleksi, menentukan fokus, menyederhanakan, meringkas, dan merubah bentuk data mentah yang ada dalam catatan laporan. Dalam proses ini dilakukan penajaman, pemfokusan, penyelisihan data yang kurang bermakna dan menatanya sedemikian rupa sehingga kesimpulan terakhir dapat di tarik dan diverifikasi. Kesimpulan yang pertama dengan yang terakhir saling terkait dan kesimpulan pertama dianggap sebagai pijakan. 


\section{Hasil dan Pembahasan}

Tindakan siklus I dilaksanakan selama 1 minggu mulai tanggal 3 Agustus 2018 sampai 8 Agustus 2018. Penelitian ini dilaksanakan dengan menggunakan metode penelitian tindakan kelas yang terdiri siklus-siklus, tiap siklus terdiri dari 3 tahapan. Adapun tahapan yang dilaksanakan adalah sebagai berikut:

1. Perencanaan

Guru sebagai pengelola pembelajaran di kelas mempersiapkan program tahunan, program semester, perencanaan pembelajaran dengan media gambar, lembar observasi, dan lembar tugas. Berdasarkan hasil observasi terhadap proses pembelajaran dan prestasi belajar sebelum tindakan, dapat diperoleh informasi data awal. Hasil pencatatan menunjukkan bahwa dari dari siswa kelas I sebanyak 10 siswa terdapat 7 siswa atau $70 \%$ yang masih belum mempu membaca permulaan dan mencapai KKM (Kriteria Ketuntasan Minimal). Setelah dilakukan pemeriksaan pada lembar pekerjaan siswa, ternyata sebagian besar siswa masih belum dapat membedakan bentuk-bentuk huruf dan pemahaman siswa banyak yang terbalik membedakan huruf satu dengan yang lainnya.

Berdasarkan pengamatan dan pencatatan terhadap proses pembelajaran dan hasil belajar tersebut diperoleh informasi sebagai data awal bahwa siswa kelas I SD Negeri 32 Sungai Jaring sebanyak 10 siswa yang mana sebagian besar siswa belum dapat memahami/ menguasai bentuk-bentuk huruf, sehingga mereka masih kesulitan membedakannya dan terbalik menggunakannya. Bertolak dari kenyataan ada melaksanakan pembelajaran bahasa Indonesia dengan menggunakan media gambar untuk mengatasi kesulitan belajar membaca permulaan siswa kelas I SD Negeri 32 Sungai Jaring.

Dengan berpedoman pada standar kompetensi mata pelajaran bahasa Indonesia, guru kelas melakukan langkah-langkah pembelajaran bahasa Indonesia dilakukan dengan menggunakan media gambar. Berikut ini merupakan langkah-langkah yang dilakukan dalam proses persiapan pembelajaran, yaitu sebagai berikut:

a. Memilih pokok bahasan atau indikator yang sesuai dengan membaca permulaan.

Indikator yang tepat untuk siklus I adalah siswa mampu mengucapkan huruf vokal dan konsonan.

b. Menyusun rencana pembelajaran berdasarkan indikator yang telah dibuat. Rencana pembelajaran yang disusun oleh peneliti memuat 1 kali pertemuan, dalam waktu 2 jam pelajaran dilaksanakan dalam 1 minggu.

c. Menyiapkan media gambar yang akan digunakan dalam pembelajaran. Pada siklus I guru menggunakan media gambar yang di bawahnya ada nama dari gambar tersebut, namun hurufnya belum lengkap (masih ada yang kosong). Untuk itu siswa diminta melengkapi huruf apa yang tepat untuk mengisi bagian yang kosong tersebut. Pada siklus I ini, guru menggunakan gambar yang nama di bawahnya terdapat huruf yang kosong baik di depan, tengah, maupun di belakang, dan siswa diminta untuk melengkapinya.

2. Pelaksanaan Tindakan

Guru menerapkan pembelajaran dengan menggunakan media gambar sesuai dengan rencana pembelajaran yang telah disusun. Pembelajaran yang telah disusun pada siklus I dengan menggunakan media gambar ini dilaksanakan dalam 1 kali pertemuan. Pada pertemuan pada siklus I materi bahasa Indonesia yang diajarkan tentang membaca permulaan dengan indikator mengucap huruf vokal dan konsonan sampai mampu membaca suku kata. Kemudian diawali dengan berdoa bersama, kemudian diajukan absensi siswa. Pada penelitian siklus I ini, guru memilih pokok bahasan tentang rekreasi. Alasan memilih pokok bahasan rekreasi karena media 
gambar yang akan digunakan guru sebagian besar adalah gambar binatang. Tujuannya agar siswa lebih tertarik dengan pelajaran dan aktif dalam mengikuti proses pembelajaran. Setelah kegiatan berdoa bersama dan absensi siswa selesai, kemudian guru mengawali pelajaran dengan appersepsi. Setelah appersepsi, guru mulai memasuki materi dengan menggunakan media gambar. Media gambar yang digunakan pada siklus I ini adalah gambar binatang yang dibawahnya terdapat nama dari binatang tersebut. Tulisan nama binatang tersebut hurufnya tidak lengkap, jadi siswa diberi tugas untuk melengkapinya. Kegiatan itu dilaksanakan secara berulangulang hingga indikatornya dapat tercapai, yaitu mampu mengucapkan huruf vokal dan konsonan. Contoh dari kegiatan tersebut adalah: misalnya guru menunjukkan gambar burung, dan di bawah gambar tersebut ada tulisan nama dari gambar tersebut. Tulisan tersebut adalah B....RUNG, kemudian siswa diminta menyebut huruf apa yang tepat untuk melengkapi kata tersebut.

Secara rinci jalannya kegiatan pada siklus I ini adalah sebagai berikut: Sebagai kegiatan awal, guru menunjukkan media yang berupa bentuk-bentuk huruf dari A sampai Z, kemudian siswa disuruh mengucapkan semua susunan huruf tersebut, dan juga hurufnya ditunjuk secara diacak. Kegiatan ini bertujuan supaya siswa ingat akan bentuk-bentuk huruf tersebut. Setelah kegiatan itu selesai, guru menunjukkan media gambar contohnya sebagai berikut :

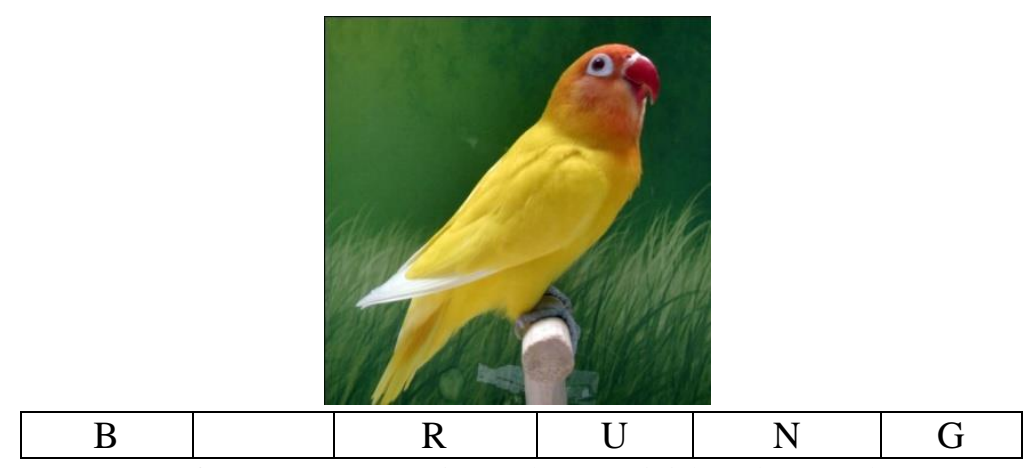

Huruf apa yang sesuai untuk mengisi kotak yang kosong?

Gambar 1. Contoh flashcard

Kegiatan semacam ini diulang-ulang dengan gambar yang berbeda-beda sampai siswa mengetahui betul tentang materi yang diajarkan ( mampu mengucapkan huruf vokal dan konsonan). Untuk mengetahui keberhasilan materi, guru menunjuk salah satu siswa untuk menyebut nama dari gambar yang ditunjukkan oleh guru, dan menyebutkan huruf apa yang tepat untuk mengisi bagian yang kosong dari nama gambar tersebut, dan menulisnya di papan tulis.

3. Observasi

Selama pelaksanaan penelitian tindakan kelas, guru melakukan pencatatan dengan menggunakan daftar observasi (check list). Mendiagnosis keaktifan siswa, nilai yang dicapai siswa, tingkat ketertarikan siswa terhadap pelajaran, tingkat keantusiasan, keaktifan membaca permulaan, kemampuan membedakan huruf, dan kemampuan membaca permulaan siswa. Pada pelaksanaan siklus I ini, hasil observasi peneliti menunjukkan bahwa: keaktifan siswa sedang, nilai yang dicapai siswa sedang, tingkat ketertarikan siswa terhadap pelajaran sedang, tingkat keantusiasan sedang, keaktifan membaca permulaan sedang, kemampuan membedakan huruf rendah, dan kemampuan membaca permulaan siswa rendah. 


\section{Refleksi}

Berdasarkan hasil observasi yang dilakukan selama proses pelaksanaan tindakan, baru 4 siswa yang sudah mulai menunjukkan adanya peningkatan. Para siswa tersebut sudah mulai mampu membedakan bentuk huruf dan sedikit-sedikit mampu melengkapi kata yang hurufnya kurang lengkap.

Berdasarkan hasil pengamatan selama proses pembelajaran berlangsung, siswa cukup aktif memperhatikan apa yang disampaikan guru dan mampu menjawab pertanyaan yang diajukan guru. Kemampuan siswa dalam membedakan bentuk huruf, pada siklus I sudah menunjukkan perubahan yang belum berarti, karena nilai rata-rata kelas hanya mencapai 60, namun siswa yang memperoleh nilai diatas KKM sebanyak 4 siswa atau $40 \%$ dari 10 siswa kelas I. Dengan demikian nilai rata-rata kelas yang mencapai 60 dan siswa yang memperoleh nilai di atas KKM sebanyak 40\% menunjukkan bahwa pembelajaran yang menggunakan media gambar pada siklus I yang dilakukan belum berhasil, jadi perlu dilakukan penelitian lagi pada siklus 2 .

Tindakan Siklus 2 dilaksanakan dalam waktu 1 minggu mulai 10 Agustus 2018 sampai dengan 14 Agustus 2018. Adapun tahapannya kegiatan yang dilaksanakan meliputi:

1. Perencanaan Tindakan

Berdasarkan hasil refleksi dan evaluasi pelaksanaan tindakan pada siklus I diketahui bahwa belum menunjukkan adanya peningkatan prestasi belajar yang memuaskan. Karena dari tiga indikator yang ditetapkan baru indikator nomor 1 dan 2 yang berhasil (mampu mengucapkan huruf vokal dan konsonan). Sedangkan indikator nomor 3, belum menunjukkan peningkatan prestasi belajar yang diinginkan. Oleh karena itu peneliti dengan arahan dari para rekan guru dan kepala sekolah serta berbagai pertimbangan maka peneliti kembali mengulang pembelajaran materi bahasa Indonesia (membaca permulaan) dengan indikator mampu membaca suku kata dan kata dengan lafal yang tepat. Guru menunjukkan media gambar, setelah itu siswa menyebutkan hurufnya. Setelah siswa selesai menyebutkan huruf-huruf tersebut, guru menyuruh siswa untuk membaca suku katanya.

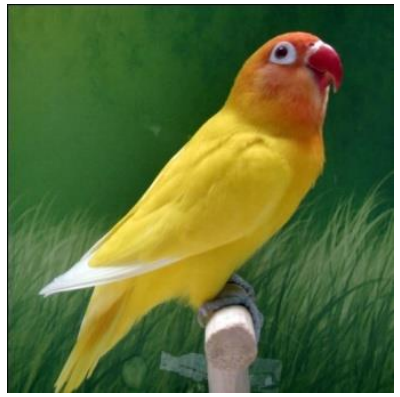

\begin{tabular}{|c|c|}
\hline B & $\mathrm{U}$ \\
\hline \multicolumn{2}{|c|}{} \\
\hline $\mathrm{R}$ & $\mathrm{U}$ \\
\hline $\mathrm{N}$ & $\mathrm{G}$ \\
\hline
\end{tabular}

Bacalah suku katanya dengan tepat dan nyaring!

Gambar 2. Contoh flashcard

Langkah-langkah penyusunan rencana pembelajaran seperti siklus I. indikator yang tepat untuk siklus 2 adalah siswa mampu mengucapkan suku kata/kata dengan lafal yang tepat. Adapun indikator yang dibuat sebagai dasar penyusunan rencana pembelajaran pada siklus 2 adalah sebagai berikut :

a. Memilih/menentukan kompetensi dasar, hasil belajar dan indikator yang hendak dicapai.

b. Mempersiapkan alat-alat/media yang akan digunakan.

c. Menyusun rencana pelaksanaan pembelajaran ( RPP ) berdasarkan kesepakatan yang telah disepakati bersama. 
Mengingat hasil analisis siklus I, sebagian besar siswa masih mengalami kesulitan membaca suku kata/ kata dengan lafal yang tepat, maka rencana penelitian pada siklus 2 ini adalah peneliti menggunakan media gambar dan kartu suku kata.

Langkah-langkah penyusunan rencana pembelajaran seperti siklus I. Indikator yang tepat untuk siklus 2 adalah siswa mampu mengucapkan suku kata/kata dengan lafal yang tepat. Adapun indikator yang dibuat sebagai dasar penyusunan rencana pembelajaran pada siklus 2 adalah sebagai berikut :

a. Memilih/menentukan kompetensi dasar, hasil belajar dan indikator yang hendak dicapai.

b. Mempersiapkan alat-alat/media yang akan digunakan.

c. Menyusun rencana pelaksanaan pembelajaran ( RPP ) berdasarkan kesepakatan yang telah disepakati bersama.

Mengingat hasil analisis siklus I, sebagian besar siswa masih mengalami kesulitan membaca suku kata/ kata dengan lafal yang tepat, maka rencana penelitian pada siklus 2 ini adalah peneliti menggunakan media gambar dan kartu suku kata.

2. Pelaksanaan Tindakan

Pembelajaran bahasa Indonesia dengan penggunaan media gambar sesuai dengan rencana pembelajaran 1 kali pertemuan. Guru mengawali pembelajaran dengan berdoa bersama, mengabsen siswa, kemudian untuk memusatkan konsentrasi, siswa diajak tanya jawab tentang pelajaran yang lalu. Pada penelitian siklus 2 ini, guru memilih pokok bahasan tentang rekreasi. Setelah kegiatan berdoa bersama dan absensi siswa selesai, kemudian guru mengawali pelajaran dengan appersepsi.

Setelah appersepsi, guru mulai memasuki materi dengan menggunakan media gambar. Media gambar yang digunakan pada siklus 2 ini adalah gambar binatang. Kemudian guru bertanya tentang nama dari gambar hewan tersebut. Setelah itu siswa ditugaskan untuk mengucapkan kata tersebut dan juga mengucapkan suku kata tersebut. Setelah kegiatan itu, secara bergiliran siswa disuruh menulis di papan tulis tentang nama dari gambar binatang tersebut.

Selanjutnya siswa menyebutkan huruf apa saja yang terangkai menjadi kata/sebuah nama binatang tersebut. Kegiatan itu dilaksanakan secara berulang-ulang hingga indikatornya dapat tercapai, yaitu mampu mengucapkan suku kata/ kata dengan lafal yang tepat.

3. Observasi

Peneliti, kepala sekolah, dan rekan guru secara kolaboratif melaksanakan observasi terhadap pelaksanaan pembelajaran dengan menggunakan media gambar. Observasi ini ditujukan pada kegiatan siswa, yaitu mendiagnosis keaktifan siswa, nilai yang dicapai siswa, tingkat ketertarikan siswa terhadap pelajaran, tingkat keantusiasan, keaktifan membaca permulaan, kemampuan membedakan huruf, dan kemampuan membaca permulaan siswa. Keseluruhan data yang diperoleh dalam kegiatan ini termasuk pencatatan hasil test akan digunakan sebagai bahan atau masukan untuk menganalisis perkembangan prestasi belajar membaca permulaan siswa. Hasil observasi pada siklus 2 adalah sebagai berikut: keaktifan siswa tinggi, nilai yang dicapai siswa sedang, tingkat ketertarikan siswa terhadap pelajaran tinggi, tingkat keantusiasan tinggi, keaktifan membaca permulaan sedang, kemampuan membedakan huruf tinggi, dan kemampuan membaca permulaan sedang.

4. Refleksi

Refleksi dilaksanakan oleh peneliti sebagai guru kelas I, hasil analisis data pada pelaksanaan pembelajaran dengan menggunakan media gambar pada siklus 2, secara umum telah menunjukkan perubahan yang cukup tinggi. Guru dalam melaksanakan pembelajaran semakin mantap dan luwes dengan memahami kekurangan-kekurangan 
kecil diantaranya kurang control waktu dan belum memberikan tindak lanjut. Presentase hasil belajar dan partisipasi siswa dalam pembelajaran terlihat meningkat drastis. Para siswa lebih banyak memperhatikan dan menjawab pertanyaan guru, lebih bersemangat, dan kreatif. Kemampuan dalam mengeja huruf menjadi suatu kata lebih meningkat, yang tentunya berpengaruh terhadap kemampuan dalam membaca permulaan. Dengan partisipasi siswa dalam pembelajaran yang semakin meningkat, suasana kelas pun menjadi hidup dan lebih menyenangkan. Dari analisis hasil test pada siklus 2 ini diketahui bahwa nilai rata-rata siswa adalah 67,5 dan siswa yang memperoleh nilai di bawah batas KKM sebanyak 1 siswa atau $10 \%$.

Berdasarkan penelitian ini pembelajaran dikatakan berhasil apabila partisipasi siswa dalam pembelajaran meningkat. Selain itu hasil yang dicapai siswa melalui test akhir pembelajaran mencapai nilai rata-rata kelas 67 dan presentase siswa yang memperoleh nilai di atas KKM sebanyak $90 \%$. Atas dasar ketentuan tersebut dan melihat hasil yang diperoleh pada masing-masing siklus, maka pembelajaran membaca permulaan yang menggunakan media gambar yang dilaksanakan pada siklus 2 sudah berhasil sehingga tidak perlu dilanjutkan ke siklus berikut.

Pembelajaran bahasa Indonesia dengan materi membaca permulaan sudah bisa dikatakan berhasil. Hal tersebut terbukti nilai membaca permulaan siswa dari sebelum tindakan sampai pelaksanaan siklus 2 terus meningkat, dan nilai rata-rata kelas pun naik. Semula sebelum tindakan, nilai bahasa Indonesia dengan materi membaca permulaan ratarata kelasnya hanya 60.

Setelah diadakan tindakan yaitu mengajar dengan menggunakan media gambar, pada siklus 1 nilai rata-ratanya naik menjadi 60. Pada siklus 1 ini masih terdapat 6 siswa yang nilainya belum mencapai KKM, maka peneliti melanjutkan penelitian siklus 2 . Pada siklus 2 ini, nilai rata-rata kelas naik menjadi 67, 5. Maka, tidak dilanjutkan ke siklus 3 karena sudah mencapai $90 \%$ siswa yang berhasil. Pada siklus 3 ini, presentase siswa yang sudah berhasil pembelajaran membaca permulaannya adalah sebanyak $92,3 \%$ dengan nilai ratarata $78,5 \%$.

Pada penelitian ini, masih terdapat 1 siswa yang nilainya belum mencapai KKM. Hal tersebut terjadi karena faktor dari siswa itu sendiri. Siswa tersebut memiliki sifat yang pemalas, kurang motivasi dari orang tua, di rumah tidak ada yang mau membimbing belajar, dan pada saat mengikuti pelajaran selalu bermain sendiri. Setiap kali dinasehati guru, siswa tersebut diam, namun tidak menghiraukan. Siswa tersebut tetap bermain tanpa merespon pelajaran, karena dengan alasan malas belajar.

Mengajar dengan menggunakan media gambar ini mampu menumbuhkan siswa lebih mudah mengingat bentuk huruf, cara mengucapkan huruf, cara mengeja suku kata, dan cara membaca suatu kata, sehingga siswa menjadi lebih termotivasi dan tertarik dalam pelajaran membaca permulaan.

\section{Kesimpulan}

Berdasarkan hasil penelitian ini, penggunaan media gambar dalam pembelajaran dapat mengatasi kesulitan belajar membaca permulaan pada siswa kelas I SD Negeri 32 Sungai Jaring dibandingkan dengan pembelajaran yang sebelum menggunakan media gambar. Hal ini dapat diketahui dari rata-rata prestasi belajar siswa yang relatif lebih tinggi bila proses pembelajarannya menggunakan media gambar dibandingkan dengan nilai ratarata siswa yang pembelajarannya sebelum menggunakan media gambar. Nilai rata-rata siswa yang pembelajarannya menggunakan media gambar adalah 67,5 , sedangkan nilai rata-rata siswa yang pembelajarannya sebelum menggunakan media gambar adalah 59. Dengan demikian berdasarkan penelitian tindakan kelas dengan menggunakan 2 siklus tersebut di atas, ternyata hipotesis yang dirumuskan telah terbukti kebenarannya, artinya 
bahwa ternyata dengan menerapkan pembelajaran dengan menggunakan media gambar dapat mengatasi kesulitan belajar membaca permulaan siswa kelas I SD Negeri 32 Sungai Jaring. Dapat disimpulkan bahwa pembelajaran bahasa Indonesia dengan menggunakan media gambar dapat mengatasi kesulitan belajar membaca permulaan pada siswa kelas I SD Negeri 32 Sungai Jaring.

\section{Bibliografi}

Ananda, Rizki. (2019). Penerapan Metode Mind Mapping untuk Meningkatkan Kemampuan Berpikir Kreatif Siswa Sekolah Dasar. Edukatif: Jurnal Ilmu Pendidikan, 1(1), 1-10.

Asy'ari, M. Kholil. (2017). Metode Pendidikan Islam. Qathrunâ, 1(01), 193-205.

Dewi, Ida Ayu Made Sasmita. (2019). Manajemen Risiko. Bali: Unhi Press.

Ginting, Dinamika. (2019). Meningkatkan Hasil Belajar Siswa Dengan Menggunakan Model Make A Match Pada Mata Pelajaran Ips Materi Memlihara Lingkungan Alam Dan Buatan Di Sekitar Rumah Di Kelas Iii Sd Negeri 040469 Surbakti Tahun Pelajaran 2018/2019. Medan: Universitas Quality.

Gunawan, Candra. (2020). Pengaruh Game Online Mobile Legend Terhadap Interaksi Sosial Remaja Di Rukun Warga 13 Kelurahan Tamansari Bandung. Bandung: FKIP UNPAS.

Halim, Abdul. (2012). Pengaruh strategi pembelajaran dan gaya belajar terhadap hasil belajar fisika siswa SMP N 2 Secanggang Kabupaten Langkat. Jurnal Tabularasa, 9(2), 141-158.

Hanifah, Nurdinah. (2014). Memahami penelitian tindakan kelas: teori dan aplikasinya. Bandung: UPI Press.

Hidayah, Nurul. (2015). Penanaman Nilai-Nilai Karakter dalam Pembelajaran Bahasa Indonesia di Sekolah Dasar. TERAMPIL: Jurnal Pendidikan Dan Pembelajaran Dasar, 2(2), 190-204.

Idzhar, Ahmad. (2016). Peranan guru dalam meningkatkan motivasi belajar siswa. Jurnal Office, 2(2), 221-228.

Ihsan, Muhammad Thoriqul. (2021). Pemikiran Ali Sya'riati dan perjuangannya dalam Revolusi Islam Iran (1933-1977). Surabaya: UIN Sunan Ampel Surabaya.

Kurnia, Rita. (2019). Bahasa Anak Usia Dini. Yogyakarta: Deepublish.

Lindawati, Ni Putu, Asriyani, Retny, \& Anggayana, I. Wayan Agus. (2019). Model Kooperatif Think-Pair-Share Dalam Meningkatkan Kemampuan Menulis Karangan Dialog Bahasa Inggris Mahasiswa Akademi Komunitas Manajemen Perhotelan Indonesia. LITERA: Jurnal Litera Bahasa Dan Sastra, 4(1).

Madyawati, Lilis. (2016). Strategi pengembangan bahasa pada anak. Kencana.

Octavia, Shilphy A. (2020). Motivasi belajar dalam perkembangan remaja. Yogyakarta: Deepublish.

Rahman, Taufiqur. (2018). Aplikasi model-model pembelajaran dalam penelitian tindakan kelas. Jawa Timur: CV. Pilar Nusantara.

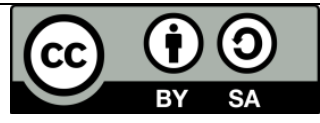

This work is licensed under a Creative Commons AttributionShareAlike 4.0 International License. 